\title{
PENGARUH VOLUME PEMBIAYAAN BAGI HASIL DAN PEMBIAYAAN MURABAHAH TERHADAP KINERJA KEUANGAN BANK UMUM SYARIAH PERIODE 2015-2020
}

\author{
Celine Quatro, Asnaini, Amimah Oktarina
}

Institut Agama Islam Negeri Bengkulu

E-mail: celinequatro26@gmail.com, asnaini@iainbengkulu.ac.id, amimahoktarina@iainbengkulu.ac.id

\begin{abstract}
This study aims to determine the effect of profit-sharing volume and murabahah financing on the performance of Islamic commercial banks for the 2015-2020 period. This research uses ECM (Error Correction Model) analysis with Eviews 8 software. The sample used in this study is 13 Islamic commercial banks that have been registered with the Indonesian Financial Services Authority (OJK). The sampling technique used the purposive sampling method because researchers needed certain criteria, namely Islamic commercial banks that have published financial ratios. The data used in this study are secondary data with documentary data collection techniques and literature studies. The results of this study indicate that the $R$ square value is 0.0362370 indicating that $36 \%$ of changes in the ROA variable can be explained by independent variables and $64 \%$ are explained by other factors outside the model.
\end{abstract}

Keywords: Profit-Sharing, Murabahah Financing, Performance

Abstrak: Penelitian ini bertujuan untuk mengetahui pengaruh volume bagi hasil dan pembiayaan murabahah terhadap kinerja bank umum syariah periode 2015-2020. Dalam penilitian ini menggunakan analisis ECM (Error Correction Model) dengan perangkat lunak Eviews 8. Sampel yang digunakan dalam penelitian ini ada 13 bank umum syariah yang telah terdaftar di OJK (Otoritas Jasa Keuangan) Indonesia. Teknik penentuan sampel menggunakan metode porpusive sampling dikarenakan peneliti membutuhkan kriteria tertentu yaitu bank umum syariah yang telah mempublikasikan rasio keuangan. Data yang digunakan dalam penelitian ini adalah data sekunder dengan teknik pengumpulan data dokumenter dan studi pustaka.Hasil penelitian ini menunjukkan nilai $R$ square 0.0362370 menunjukkan bahwa $36 \%$ perubahan pada variabel ROA dapat dijelaskan oleh variabelvariabel bebas dan $64 \%$ dijelaskan oleh faktor lain diluar model.

Kata kunci: Bagi Hasil, Pembiayaan Murabahah, Kinerja

\section{A. PENDAhUluaN}

Pertumbuhan perbankan syariah di Indonesia termasuk lambar jika di bandingkan dengan pertumbuhan perbankan syariah di Negara lain. Akan tetapi bank Indonesia tetap optimis bahwa pertumbuhan bank syariah akan meningkat mengingat prospek pangsa pasarnya dalam negeri yang besar. ${ }^{1}$ Perbankan syariah adalah suatu sistem yang dibangun dengan semangat alternative sehingga harus berbeda dengan perbankan yang telah ada. ${ }^{2}$ Bank syariah merupakan sebuah alternatif baru untuk masyarakat pengguna jasa perbankan, khususnya bagi umat muslim

${ }^{1}$ Fika Azmi, “Analisis Pengaruh Volume Pembiayaan Terhadap Profitabilitas Dengan BOPO Sebagai Variabel Moderasi Pada Bank Umum Syariah Di Indonesia,” Ebbank 7, no. 2 (2016), hlm. 93-104.

${ }^{2}$ Heftika Nur Fauziah, Aini Nur Fakhriyah, and Abdurrohman Abdurrohman, "Analisis Risiko Operasional Bank Syariah Pada Masa Pandemi Covid-19," Al-Intaj Jurnal Ekonomi dan Perbankan Syariah 6, no. 2 (2020), hlm. 38-45. 
tanpa menghawatirkan riba. ${ }^{3}$ Saat ini masyarakat sudah mulai mengetahui perbedaan antara bank konvensional dan bank syariah. Hal ini juga memiliki keuntungan bagi masyarakat terutama yang beragama islam. ${ }^{4}$ Perbankan syariah merupakan lembaga yang berfungsi sebagai penghimpun dana dan menyalurkan dana kepada masyarakat secara efektif. ${ }^{5}$ Perbankan syariah didirikan dan dikembangkan berlandaskan pada Al-Quran dan Hadist. Kegiatan dan usaha bank syariah dijalankan dengan prinsip-prinsip muamalah islam. ${ }^{6}$ Dalam ekonomi islam bermuamalah di perbolehkan selama dalam bermualah tidak mengandung unsur riba, gharar, maytsir dan tidak menimbulkan ketidak adilan bagi salah satu pihak. Prinsip yang digunakan dalam bank syariah adalah menjalankan segala bentuk kegitan keuangan untuk memperoleh keuntungan yang optimal akan tetapi tetap memperhatikan prinsip-prinsip islam. ${ }^{7}$

Pada awal perkembangannya perbankan syariah menawarkan berbagai jenis produk yang tidak mengandung bunga yaitu berupa pembiayaan bagi hasil atau yang lebih dikenal dengan ( Profit and Loss Sharing) dan pembiayaan murabahah. ${ }^{8}$ Salah satu indikator dalam mengalokasikan dana adalah seberapa besar pembiayaan yang disalurkan oleh bank kepada nasabah, penyaluran dana yang dilakukan oleh bank adalah antara lain, pembiayaan jual beli, bagi hasil, dan sewa ${ }^{9}$. Sistem bagi hasil merupakan sistem dilakukannya perjanjian atau ikatan bersama dalam melakukan kegiatan usaha. ${ }^{10}$ Sistem bagi hasil yang di terapkan pada perbankan syariah mempertahankan kinerja bank dan tidak terganggu dengan tingkat suku bunga simpanan yang melonjak sehingga beban operasional rendah. ${ }^{11}$ Pembiayaan dengan prinsip bagi hasil diimplementasikan kedalam dua bentuk pembiayaan yaitu pembiayaan mudharabah dan pembiayaan musyarakah. ${ }^{12}$

${ }^{3}$ Ian Azhar and Arim Nasim, "Pengaruh Pembiayaan Jual Beli, Pembiayaan Bagi Hasil, Dan Non Performing Finance Terhadap Profitabilitas (Studi Kasus Pada Bank Umum Syariah Di Indonesia Periode 2012 2014)," Jurnal ASET (Akuntansi Riset) 8, no. 1 (2016), hlm. 51.

${ }^{4}$ Ratu Vien Sylvia Aziza and A D E Sofyan Mulazid, “Analisis Pengaruh Dana Pihak Ketiga, Non Performing Financing, Capital Adequacy Ratio, Modal Sendiri Dan Marjin Keuntungan Terhadap Pembiayaan Murabahah," Jurnal Ekonomi dan Bisnis Islam (JEBI) 2 (2015), hlm. 1-15.

${ }^{5}$ Amimah Oktarina and Asnaini Asnaini, "Potensi Kontribusi Institusi Pendidikan Islam Terhadap Perkembangan Bank Syari'ah Di Indonesia,” Al-Intaj : Jurnal Ekonomi dan Perbankan Syariah 6, no. 1 (2020): 51.

${ }^{6}$ Setia Budhi Wilarjo, "Pengertian, Peranan, Dan Perkembangan Bank Syariah Di Indonesia," Igarss 2014 2, no. 1 (2014), hlm. 1-5.

${ }^{7}$ Mirasanti Wahyuni, "Pengaruh Volume Pembiayaan Bagi Hasil Dan Pembiayaan Murabahah Terhadap Kinerja Keuangan Bank Umum Syariah Dengan NPF Sebagai Variabel Moderasi,” Jurnal EBBANK 7, no. 1 (2016), hlm. 1-10.

${ }^{8}$ Novi Fadhila, “Analisis Pembiayaan Mudharabah Dan Murabahah Terhadap Laba Bank Syariah Mandiri," Riset Akuntansi Dan Bisnis 15, no. 1 (2015), hlm. 52-64.

${ }^{9}$ Dila Angraini, "Pengaruh Dana Pihak Ketiga, Non Performing Financing, Tingkat Bagi Hasil Dan Modal Sendiri Terhadap Profitabilitas Dengan Pembiayaan Bagi Hasil Sebagai Variabel Intervening Pada Perbankan Syariah," Jurnal Akuntansi Berkelanjutan Indonesia 1, no. 1 (2018), hlm. 122.

${ }^{10}$ Vidya Fathimah, "Pengaruh Perkembangan Jumlah Tabungan, Deposito Dan Bagi Hasil Terhadap Jumlah Pembiayaan Yang Diberikan Oleh Perbankan Syariah Di Sumatera Utara,” Jurnal Ilman 5, no. 1 (2017), hlm. $41-52$.

${ }^{11}$ Muh Sabir M, Muhammad Ali, and Abd Hamid Habbe, "Pengaruh Rasio Kesehatan Bank Terhadap Kinerja Keuangan Bank Umum Syariah Dan Bank Konvensional Di Indonesia,” Jurnal Analisis 1, no. 1 (2012), hlm. 79-86.

${ }^{12}$ Sofhian and Sri Nur Ain Suleman, "Manajemen Penyelesaian Pembiayaan Bermasalah Pada Lembaga Perbankan,” Jurnal Studi Ekonomi dan Bisnis Islam I (2017), hlm. 56-74. 
Mudharabah adalah kerja sama antara kedua belah pihak dimana pihak pertama sebagai (shahibul maal) yang menyediakan modal, sedangkan pihak lainnya sebagai pengelola. ${ }^{13}$ Musyarakah adalah kerjasama antara dua pihak atau lebih untuk melakukan usaha tertentu dan masing-masing pihak memberikan kontribusi dana, keahlian/manajerial dengan kesepakatan keuntungan dalam kontrak dan kerugian ditanggung bersama-sama sesuai dengan jumlah modal yang disertakan. ${ }^{14}$ Namun pada prakteknya pembiayaan di bank syariah tidak didominasi oleh pembiayaan bagi hasil mudharabah akan tetapi di dominasi oleh pembiayaan murabahah. ${ }^{15}$ Keunggulan dari pembiayaan murabahah adalah nasabah dapat membeli suatu barang sesuai dengan keinginan, dan kemampuan ekonominya, selain itu pembiayaannya dilakukan dengan angsuran sehingga tidak memberatkan nasabah nasabah itu sendiri. ${ }^{16}$ Pembiayaan murabahah adalah jual beli antara kedua belah pihak yaitu nasabah dan lembaga keuangan dimana lembaga keuangan menyebutkan jumlah keuntungan tertentu. ${ }^{17}$ Besarnya tingkat margin murabahah akan memepengaruhi minat nasabah untuk memanfaatkan pembiayaan murabahah, jadi semakin tinggi margin murabahah semakin mahal juga harga pembiayaan akad murabahah. ${ }^{18}$

Dalam kerjasama murabahah penjual harus memberitahu harga produk yang dibeli dan menentukan tingkat keuntungan sebagai tambahan. ${ }^{19}$ Dalam pembiayaan dengan prinsip bagi hasil keuntungan yang di peroleh di tentukan oleh nisbah yang telah disepakati antara dua belah pihak di perjanjian awal. ${ }^{20}$ Perbaikan kinerja keuangan bank syariah perlu dilakukan yaitu dengan meningkatkan jumlah volume pembiayaan yang di salurkan harus ditingkatkan terutama pada pembiayaan produktif. ${ }^{21}$ Ada beberapa factor yang mempengaruhi kenerja keuangan bank syariah, dalam penelitian Mirasanti Wahyuni (2016) adalah besarnya volume pembiayaan di duga mempengaruhi kinerja bank umum syariah. Penelitian ini dilakukan untuk mengetahui seberapa besar pengaruh volume pembiayaan terhadap kinerja bank umum syariah kinerja bank umum syariah diproksikan dengan ROA . ROA adalah kemampuan bank dalam menghasilkan

\footnotetext{
${ }^{13}$ Rina Destiana, “Analisis Dana Pihak Ketiga Dan Risiko Terhadap Pembiayaan Mudharabah Dan Musyarakah Pada Bank Syariah Di Indonesia,” LOGIKA Jurnal Ilmiah Lemlit Unswagati Cirebon 17, no. 2 (2016), hlm. 42-54.

${ }^{14}$ Amirus Sodiq and Ela Chalifah, "Pengaruh Pendapatan Mudharabah Dan Musyarakah Terhadap Profitabilitas (ROA) Bank Syariah Mandiri Periode 2006-2014," EQUILIBRIUM:Jurnal Ekonomi Syariah 3, no. 1 (2015), hlm. 27-47.

${ }^{15}$ Yenti Afrida, “Analisis Pembiayaan Murabahah Di Perbankan Syariah,” Jebi (Jurnal Ekonomi Dan Bisnis Islam) 1, no. 2 (2016), hlm. 155-166.

${ }^{16}$ Bagya Agung Prabowo, "Konsep Akad Murabahah Pada Perbankan Syariah (Analisa Kritis Terhadap Aplikasi Konsep Akad Murabahah Di Indonesia Dan Malaysia),” Jurnal Hukum Ius Quia Iustum 16, no. 1 (2009), hlm. 106-126.

${ }^{17}$ (Agzaand Darwanto 2017)

${ }^{18}$ Fadhila, "Analisis Pembiayaan Mudharabah Dan Murabahah Terhadap Laba Bank Syariah Mandiri."

${ }^{19}$ Strategi Penyelamatan et al., "Januari-Juni 2016 Referring to the NPF Data of Syariah Mandiri Bank," Junal Ekonomi Islam el-JIZYA 4, no. 1 (2016): 2015.

${ }^{20}$ Masiyah Kholmi, "Ekonomi Dan Bisnis," Akuntabilitas dalam Perspektif Teori Agensi 02, no. 02 (2010), hlm. 357-370.

${ }^{21}$ Azmi, “Analisis Pengaruh Volume Pembiayaan Terhadap Profitabilitas Dengan BOPO Sebagai Variabel Moderasi Pada Bank Umum Syariah Di Indonesia."
} 
laba atau pengkuran kemampuan bank dalam mengelola sejumlah assetuntuk menghasilkan laba. $^{22}$

\section{B. METODE PENELITIAN}

Metode yang digunakan dalam penelitian ini adalah metode pendekatan kuantitatif. Populasi dalam penelitian ini adalah bank umum syariah di Indonesia yang terdaftar di OJK yang berjumlah 13 Bank. ${ }^{23}$ Teknik pengambilan sampel dalam penelitian ini adalah porpusive sampling. ${ }^{24}$ Keriteria dalam penelitian ini adalah bank umum syariah yang terdaftar di statistik perbankan syariah, bank umum syariah yang mempublikasikan rasio keuangan secara runtut dan lengkap.

Data yang digunakan adalah data sekunder. Data diperoleh dari jurnal, laporan keuangan yang terpublikasi dan statistika perbankan syaraiah yang terdapat di OJK. Data yang digunakan dalam penelitian ini adalah ini adalah sebanyak 68 data laporan keuangan perbulan yang terpublikasi di statistika perbankan syariah. Teknik analisis data yang digunakan dalam penelitian ini adalah Eror Correction Model (ECM) dengan perangkat lunak Eview 8. ECM merupakan tehnik analisis untuk mengkoreksi ketidakseimbangan jangka pendek dan jangka panjang yaitu untuk mengetahui pengaruh volume pembiayaan bagi hasil dan pembiayaan murabahah terhadap ROA. ${ }^{25}$

\section{HASIL DAN PEMBAHASAN}

\section{Uji Akar-Akar Unit (Unit Root Test)}

Tabel 1 hasil uji akar-akar (Augment Dickey-Fuller Test di Level) Null Hypothesis: LNBAGIHASIL has a unit root

\begin{tabular}{lcc}
\hline Exogenous: Constant & & \\
\hline \hline & t-Statistic & Prob. ${ }^{*}$ \\
\hline \hline Augmented Dickey-Fuller test statistic & -1.809888 & 0.3728 \\
\hline Test critical values: $1 \%$ level & -3.531592 & \\
\hline 5\% level & -2.905519 & \\
\hline 10\% level & -2.590262 & \\
\hline
\end{tabular}

Sumber : Data diolah, 2021

\footnotetext{
${ }^{22}$ Iqbal Notoadmojo and Anita Rahmawaty, "Analisis Faktor-Faktor Yang Memengaruhi Financial Sustainability Ratio Pada Bank Umum Syariah Di Indonesia Periode 2010 - 2014,” Equilibrium: Jurnal Ekonomi Syariah 4, no. 1 (2017), hlm. 20.

${ }^{23}$ Otoritas Jasa Keuangan, "Statistik Perbankan Syariah Agustus 2020” (2020), hlm. 117

${ }^{24}$ Lilis Sudarwati, "Pengaruh Pembiayaan Bagi Hasil Dan Pembiayaan Jual Beli Terhadap Profitabilitas (Roa) Dengan Non Performing Financing (Npf) Sebagai Variabel Intervening," Skripsi, IAIN SALATIGA (2018), hlm.1-135.

${ }^{25}$ Dwi Widiarsih and Reza Romanda, “Analisis Faktor-Faktor Yang Mempengaruhi Inflasi Di Indonesia Tahun 2015-2019 Dengan Pendekatan Error Corection Model (ECM)," Jurnal Akuntansi dan Ekonomika 10, no. 1 (2020), hlm. 119-128.
} 
Null Hypothesis: LNMURABAHAH has a unit root

\begin{tabular}{lll}
\hline Exogenous: Constant & & \\
\hline \hline & t-Statistic & Prob. ${ }^{*}$ \\
\hline \hline Augmented Dickey-Fuller test statistic & -2.078310 & 0.2539 \\
\hline Test critical values: $1 \%$ level & -3.531592 & \\
\hline 5\% level & -2.905519 & \\
\hline 10\% level & -2.590262 & \\
\hline \hline
\end{tabular}

Sumber : Data diolah, 2021

Null Hypothesis: ROA has a unit root

Exogenous: Constant

\begin{tabular}{lcc}
\hline \hline & t-Statistic & Prob.* \\
\hline \hline Augmented Dickey-Fuller test statistic & -1.637301 & 0.4582 \\
\hline Test critical values: $1 \%$ level & -3.531592 & \\
5\% level & -2.905519 & \\
10\% level & -2.590262 & \\
\hline \hline
\end{tabular}

Sumber : Data diolah, 2021

Pada tabel 1, telah peroleh hasil uji variabel penelitian pada tingkat level namun hasil uji menunjukkan bahwa variabel tidak stasioner karena nilai prob melebihi 0.005. Oleh karena itu agar semua variabel stasioner di angka yang sama maka perlu di lakuakn uji stasioner pada tingkat $1^{\text {st }}$ Difference.

Tabel 2.Hasil Uji Akar-Akar Unit (Augmen Dickey-Fuller Test di $1^{\text {st }}$ Difference) Null Hypothesis: D(LNBAGIHASIL) has a unit root Exogenous: Constant

\begin{tabular}{|c|c|c|}
\hline & t-Statistic & Prob.* \\
\hline Augmented Dickey-Fuller test statistic & -8.594000 & 0.0000 \\
\hline \multirow[t]{2}{*}{ Test critical values: } & -3.533204 & \\
\hline & -2.906210 & \\
\hline $10 \%$ level & -2.590628 & \\
\hline
\end{tabular}

Sumber : Data diolah, 2021 
Null Hypothesis: D(LNMURABAHAH) has a unit root Exogenous: Constant

\begin{tabular}{lll}
\hline \hline & t-Statistic & Prob. ${ }^{*}$ \\
\hline \hline Augmented Dickey-Fuller test statistic & -7.929769 & 0.0000 \\
\hline Test critical values: $1 \%$ level & -3.533204 & \\
5\% level & -2.906210 & \\
$10 \%$ level & -2.590628 & \\
\hline \hline
\end{tabular}

Sumber : Data diolah, 2021

Null Hypothesis: D(ROA) has a unit root

Exogenous: Constant

\begin{tabular}{llll}
\hline \hline & t-Statistic & Prob.* \\
\hline \hline Augmented Dickey-Fuller test statistic & -10.14570 & 0.0000 \\
\hline Test critical values: $1 \%$ level & -3.533204 & \\
5\% level & -2.906210 & \\
$10 \%$ level & -2.590628 & \\
\hline \hline
\end{tabular}

Sumber : Data diolah, 2021

Pada tabel 2 adalah hasil uji akar-akar unit dengan uji Augment Dickey-Fuller (ADF) test di tingkat $1^{\text {st }}$ difference semua variabel sudah stasioner pada tingkat $1^{\text {st }}$ difference dengan nilai prob 0.000. Variabel dikatakan stasioner apabila nilainya kurang dari 0.005.

\section{Uji Kointegrasi}

\section{Tabel 3. Hasil Uji Kointegrasi}

Null Hypothesis: D(RES) has a unit root

Exogenous: Constant

\begin{tabular}{lll}
\hline \hline & t-Statistic & Prob.* \\
\hline \hline Augmented Dickey-Fuller test statistic & -10.05994 & 0.0000 \\
\hline Test critical values: $1 \%$ level & -3.538362 & \\
5\% level & -2.908420 & \\
10\% level & -2.591799 & \\
\hline \hline
\end{tabular}

Sumber : Data diolah, 2021 


\section{Uji Asumsi Klasik}

\section{a. Uji Normalitas}

Tabel 4. Hasil uji normalitas

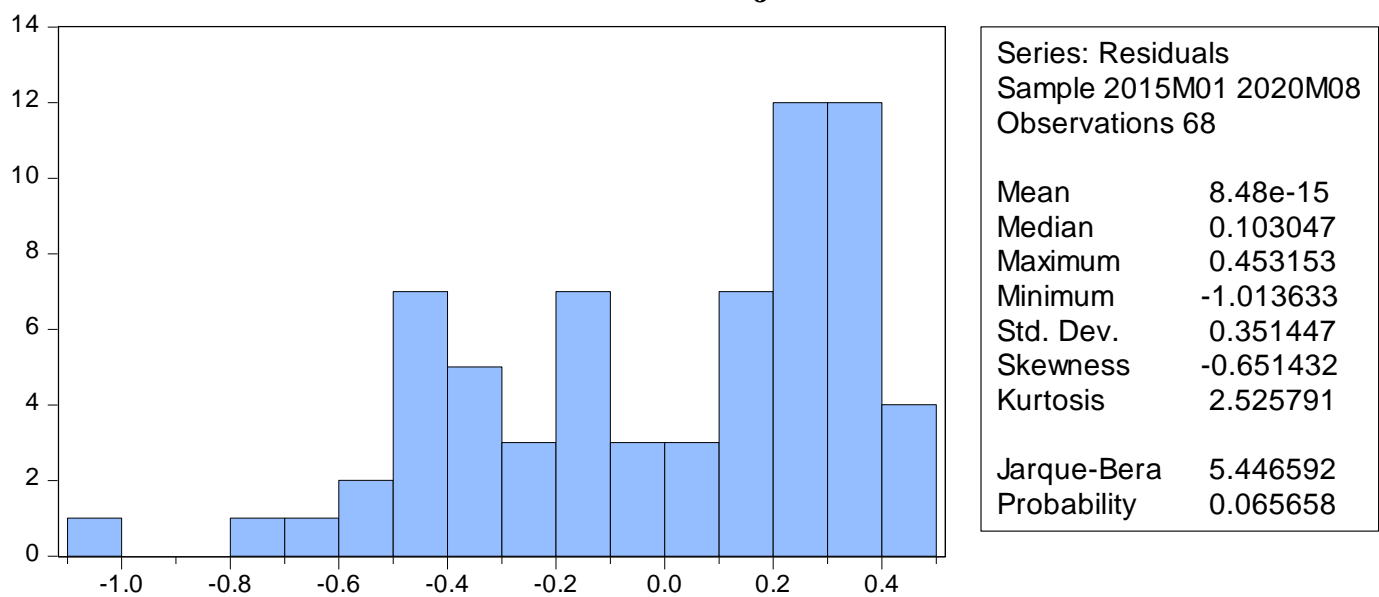

Sumber: Data diolah, 2021

Berdasarkan tabel 4 diketahui nilai Jarquare-Bera sebesar 5.446592 dengan profitability $0.06>0,05$ artinya data penelitian terdistribusi secara normal.

\section{b. Uji Heteroskedastisitas}

\section{Tabel 5. Hasil Uji Heteroskedastisitas}

Heteroskedasticity Test: White

\begin{tabular}{llll}
\hline \hline F-statistic & 4.187566 & Prob. F(4,63) & 0.0045 \\
Obs*R-squared & 14.28231 & Prob. Chi-Square(4) & 0.0064 \\
Scaled explained SS & 9.955713 & Prob. Chi-Square(4) & 0.0412 \\
\hline
\end{tabular}

Sumber : Data diolah, 2021

Berdasarkan tabel 5 diketahui nilai Prob F hitung sebesar $0.0045>0.005$. dapat disimpulkan bahwa $\mathrm{H} 0$ diterima dan tidak terjadi heteroskedastisitas

c. Uji Auto korelasi

Tabel 6. Hasil Uji Autokorelasi

Breusch-Godfrey Serial Correlation LM Test:

\begin{tabular}{llll}
\hline \hline F-statistic & 69.63608 & Prob. F(2,63) & 0.0000 \\
Obs*R-squared & 46.82061 & Prob. Chi-Square(2) & 0.0000 \\
& $=$
\end{tabular}

Sumber: Data diolah, 2021

Berdasarkan tabel 6 uji auto korelasi dengan menggunakan uji LM (Large Multiplier) diketahui Prob F hitung sebesar $0.0000<0.005$. dapat disimpulkan tidak terjadi autokolerasi 


\section{d. Uji Multikorenitas}

Tabel 7. Hasil uji multikorenitas

\begin{tabular}{|l|l|l|l|l|}
\hline & LNBAGIHASIL & LNMURABAHAH & RES & ROA \\
\hline LNBAGIHASIL & 1 & 0.9237661769939646 & -0.01365752875564845 & 0.5383981480537926 \\
\hline LNMURABAHAH & 0.9237661769939646 & 1 & 0.05143231393514417 & 0.3949375333642116 \\
\hline RES & -0.01365752875564845 & 0.05143231393514417 & 1 & 0.2378294835751544 \\
\hline ROA & 0.5383981480537926 & 0.3949375333642116 & 0.2378294835751544 & 1 \\
\hline
\end{tabular}

Sumber : Data diolah, 2021

Berdasarkan tabel 7 menunjukkan tidak terdapat nilai korelasi yang tinggi antar variabel sehingga dapat disimpulkan tidak terdapat multikorenitas antar variabel bebas.

\section{Hasil Uji Hipotesis}

\section{a. Estimasi Persamaan Jangka Panjang}

\section{Tabel 8. Hasil Uji Persamaan Jangka Panjang}

Dependent Variable: ROA

Method: Least Squares

Sample (adjusted): 2015M01 2020M08

Included observations: 68 after adjustments

\begin{tabular}{|c|c|c|c|c|}
\hline Variable & Coefficient & Std. Error & t-Statistic & Prob. \\
\hline $\mathrm{C}$ & 2.098065 & 5.934512 & 0.353536 & 0.7248 \\
\hline LNBAGIHASIL & 2.882984 & 0.635524 & 4.536385 & 0.0000 \\
\hline LNMURABAHAH & -2.853651 & 1.028342 & ( & 0.0072 \\
\hline R-squared & 0.362370 & \multicolumn{2}{|c|}{ Mean dependent var } & 1.063529 \\
\hline Adjusted R-squared & 0.342751 & \multicolumn{2}{|c|}{ S.D. dependent var } & 0.440125 \\
\hline S.E. of regression & 0.356813 & \multicolumn{2}{|c|}{ Akaike info criterion } & 0.819905 \\
\hline Sum squared resid & 8.275509 & \multicolumn{2}{|c|}{ Schwarz criterion } & 0.917825 \\
\hline Log likelihood & -24.87677 & \multicolumn{2}{|c|}{ Hannan-Quinn criter. } & 0.858704 \\
\hline F-statistic & 18.47003 & \multicolumn{2}{|c|}{ Durbin-Watson stat } & 0.369277 \\
\hline Prob(F-statistic) & 0.000000 & & & \\
\hline
\end{tabular}

Sumber : Data diolah, 2021

Berdasarkan tabel 8 maka persamaan estimasi jangka panjang $\mathrm{ROA}=2.098065+$ 2.882984 LNBagihasil -2.852651 LNMurabahah

$\mathrm{t}=(0.353536) \quad(4.536385)(-2.775002)$

F-statistik : 18.47003

R-squared $=0.362370$

Hasil estimasi jangka panjang variabel pengaruh volume pembiayaan bagi hasil dengan nilai koefisien sebesar 2.882984 artinya setiap kenaikan perubahan volume 
pembiayaan sebesar 1\% maka akan menyebabkan kenaikan presentase pembiayaan sebesar $2.8829 \%$.

Perubahan presentase pengaruh volume pembiayaan bagi hasil memiliki thitung sebesar 4.536385 dengan tingkat signifikannya sebesar 0.000 . sedangkan nilai tabel yang diperoleh sebesar 1.66757. hal ini menunjukkan thitung (4.536385) lebih besar dari tabel (1.66757) dan nilai signifikannya lebih besar dari $0.05(0.000<0.05)$, maka H1 diterima.

Hasil estimasi jangka panjang variabel pembiayaan murabahah memiliki koefisien 2.853651 , artinya setiap kenaikan variabel pengaruh pembiayaan murabahah sebesar $1 \%$, maka akan menyebabkan penurunan perubahan persentase pengaruh volume pembiayaan murabahah sebesar $-2.853 \%$. hal ini menunjukkan thitung $(-2.775002)$ lebih besar dari tabel (1.66757) maka nilai signifikansinya lebih kecil dari $0.05(0.0072<0)$, maka H2 diterima dan $\mathrm{H} 1$ ditolak artinya terdapat pengaruh yang signifikan antara pengaruh volume pembiayaan murabahah dengan variabel kinerja bank umum syariah (ROA).

Hasil uji F-statistik menunjukkan hasil signifikan sebesar $0.000<0.05$ dan didapatkan nilai Fhitung sebesar 18.47003. karena Fhitung > Ftabel $(18.47003>3.21446)$, maka $\mathrm{H} 1$ ditolak dan $\mathrm{H} 2$ diterima berarti jangka panjang variabel pembiayaan murabahah yang terdapat dalam model berpengaruh secara signifikan terhadap variabel kinerja bank umum syariah.

Untuk mengetahui seberapa besar perubahan dalam jangka panjang maka dilakukan uji determinasi. Nilai $\mathrm{R}^{\text {Square }}$ sebesar 0.362370 menunjukkan bahwa $36 \%$ perubahan pada variabel ROA mampu dijelaskan oleh variabel-variabel bebasnya dalam persamaan jangka panjang dan sisanya sebesar 64\% dijelaskan oleh factor lain diluar model.

\section{b. Estimasi persamaan jangka pendek}

\section{Tabel 9. Estimasi persamaan jangka pendek}

Dependent Variable: D(ROA)

Method: Least Squares

Sample (adjusted): 2015M04 2020M08

Included observations: 65 after adjustments

\begin{tabular}{|c|c|c|c|c|}
\hline Variable & Coefficient & Std. Error & t-Statistic & Prob. \\
\hline $\mathrm{C}$ & 0.011355 & 0.022091 & 0.514000 & 0.6091 \\
\hline D(LNBAGIHASIL) & -1.439424 & 0.792492 & -1.816326 & 0.0742 \\
\hline D(LNMURABAHAH & 2.325538 & 1.188676 & 1.956410 & 0.0550 \\
\hline $\operatorname{RES}(-1)$ & -0.207520 & 0.124987 & -1.660331 & 0.1020 \\
\hline R-squared & 0.109080 & \multicolumn{2}{|c|}{ Mean dependent var } & 0.010308 \\
\hline Adjusted R-squared & 0.065265 & \multicolumn{2}{|c|}{ S.D. dependent var } & 0.182397 \\
\hline S.E. of regression & 0.176345 & \multicolumn{2}{|c|}{ Akaike info criterion } & -0.573191 \\
\hline Sum squared resid & 1.896941 & \multicolumn{2}{|c|}{ Schwarz criterion } & -0.439382 \\
\hline Log likelihood & 22.62870 & \multicolumn{2}{|c|}{ Hannan-Quinn criter. } & -0.520395 \\
\hline
\end{tabular}




$\begin{array}{llll}\text { F-statistic } & 2.489525 & \text { Durbin-Watson stat } & 1.907060 \\ \text { Prob(F-statistic) } & 0.068706 & \end{array}$

Sumber : Data diolah, 2021

Berdasarkan tabel diatas seluruh variabel sudah ditrasformasikan dalam bentuk log, lalu dideferensiasikan dalam model Eror Correction Model (ECM) untuk mengetahui hubungan dalam estimasi persamaan jangka pendek yang diperoleh adalah :

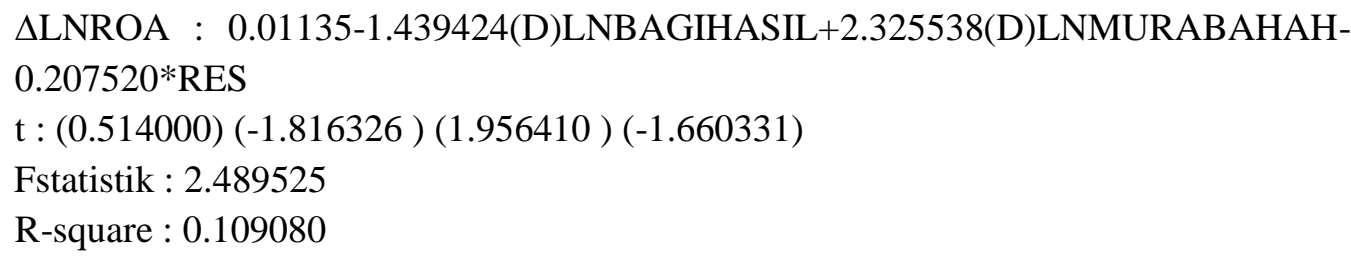

Pengaruh volume pembiayaan bagi hasil memiliki hubungan yang positif dengan ROA. Namun dari hasil estimasi model koreksi kesalahan dalam jangka pendek diperoleh koefisien regresi perubahan presentase pengaruh volume pembiayaan memiliki tanda negative yang tidak menunjukkan bahwa terjadi hubungan negative antar variabel perubahan presentase pengaruh volume pembiayaan. Dari hasil estimasi diperoleh nilai koefisien regresi perubahan dari perubahan persentase pengaruh volume pembiayaan bagi hasil sebesar -1.439424 yang menunjukkan bahwa jika terjadi perubahan pengaruh volume pembiayaan bagi hasil sebesar $1 \%$ maka akan terjadi perubahan penurunan volume pembiayaan bagi hasil sebesar $1.439 \%$. namun demikian pengaruh tersebut tidak signifikan secara statistik. Hal ini ditunjukkan oleh t-statistk sebesar -1.816326 yang lebih kecil dari nilai t-tabel yang sebesar 1.66757 pada tingkat keyakinan $95 \%$ sekalipun.

Nilai t-statistik untuk variabel perubahan volume pembiayaan murabahah adalah sebesar 2.325538. sedangkan nilai t-tabel 1.66757. hal ini menunjukkan t-thitung > t-tabel $(2.325538>1.66757)$ dan nilai signifikansinya lebih besar dari $(0.0550>0.05)$ maka H1 diterima dan $\mathrm{H} 2$ ditolak.

Hasil uji F-statistik menunjukkan hasil signifikasi sebesar 0.068706 lebih besar dari 0.05 dan didapatkan $F_{\text {hitung }}$ sebesar 2.489525. jadi Fhitung lebih besar dari Ftabel (2.489525 > 1.66757), maka H1 ditolak dan H2 diterima berarti dalam jangka pendek variabel perubahan presentase volume pembiayaan murabahah yang terdapat dalam model berpengaruh secara signifikan terhadap variabel ROA

\section{c. Uji Regresi Linear Berganda}

Tabel 10. Uji Regresi Linear Berganda

Dependent Variable: ROA

Method: Least Squares

Sample (adjusted): 2015M01 2020M08

Included observations: 67 after adjustments

Variable Coefficient Std. Error t-Statistic Prob.




\begin{tabular}{lllll} 
C & 2.537577 & 5.967820 & 0.425210 & 0.6721 \\
LNBAGIHASIL & 2.981787 & 0.646950 & 4.608993 & 0.0000 \\
LNMURABAHAH & -2.986538 & 1.041764 & -2.866810 & 0.0056 \\
\hline \hline R-squared & 0.369583 & Mean dependent var & 1.064328 \\
Adjusted R-squared & 0.349883 & S.D. dependent var & 0.443397 \\
S.E. of regression & 0.357510 & Akaike info criterion & 0.824437 \\
Sum squared resid & 8.180065 & Schwarz criterion & 0.923154 \\
Log likelihood & -24.61863 & Hannan-Quinn criter. & 0.863500 \\
F-statistic & 18.76006 & Durbin-Watson stat & 0.266793 \\
Prob(F-statistic) & 0.000000 & & \\
\hline \hline
\end{tabular}

Sumber : Data diolah, 2021

Berdasarkan hasil uji data regresi berganda nilai R-square sebesar 0.369583 yang artinnya variabel predictor sangat berpengaruh terhadap nilai lnbagi hasil 2.981787 .

\section{d. Uji Parsial ( Uji T)}

Dapat disimpulkan bahwa :

1) Pengaruh volume pembiayaan bagi hasil terhadap ROA, dari hasil uji regresi diatas dapat diketahui bagi hasil dengan signifikansi 0.000, nilai signifikan $<0.05$ berarti bagi hasil memiliki pengaruh terhadap ROA dengan arah posistif

2) Pengaruh voluime pembiayaan murabahah terhadap ROA, dari hasil uji regresi diatas dapat diketahui murabahah dengan signifikansi 0.000 , nilai signifikansi $<0.05$ berarti murabahah memiliki pengaruh terhadap ROA.

\section{e. Uji F ( Uji Simultan)}

Berdasarkan hasil uji F dapat disimpulkan bahwa : Diketahui profitabilitas F memiliki nilai yang signifikan sebesar 0.000000 . artinya nilai profitabilitas lebih kecil dari 0.05 .

\section{Hipotesis 1: Pembiayaan Bagi Hasil diduga berpengaruh positif terhadap ROA}

Hasil estimasi jangka panjang variabel pengaruh volume pembiayaan bagi hasil dengan nilai koefisien sebesar 2.882984 artinya setiap kenaikan perubahan volume pembiayaan sebesar $1 \%$ maka akan menyebabkan kenaikan presentase pembiayaan sebesar $2.8829 \%$.

Perubahan presentase pengaruh volume pembiayaan bagi hasil memiliki thitung sebesar 4.536385 dengan tingkat signifikannya sebesar 0.000. sedangkan nilai tabel yang diperoleh sebesar 1.66757. hal ini menunjukkan thitung (4.536385) lebih besar dari tabel (1.66757) dan nilai signifikannya lebih besar dari $0.05(0.000<0.05)$, maka H1 diterima.

Nilai t-statistik untuk variabel perubahan presentase volume pembiayaan bagi hasil adalah sebesar $(-1.816326)<\mathrm{t}$-tabel (1.66757) dan nilai signifikansinya lebih besar dari 0.05 $(0.0742>0.05)$. maka H1 diterima dan $\mathrm{H} 2$ ditolak.

\section{Hipotesis II : Pembiayaan Murabahah diduga berpengaruh positif terhadap ROA}

Hasil estimasi jangka panjang variabel pembiayaan murabahah memiliki koefisien 2.853651 , artinya setiap kenaikan variabel pengaruh pembiayaan murabahah sebesar $1 \%$, 
maka akan menyebabkan penurunan perubahan persentase pengaruh volume pembiayaan murabahah sebesar $-2.853 \%$. hal ini menunjukkan thitung (-2.775002) lebih besar dari tabel (1.66757) maka nilai signifikansinya lebih kecil dari $0.05(0.0072<0)$, maka H2 diterima dan $\mathrm{H} 1$ ditolak artinya terdapat pengaruh yang signifikan antara pengaruh volume pembiayaan murabahah dengan variabel kinerja bank umum syariah (ROA).

Hasil uji F-statistik menunjukkan hasil signifikasi sebesar 0.068706 lebih besar dari 0.05 dan didapatkan $F_{\text {hitung }}$ sebesar 2.489525. jadi Fhitung lebih besar dari Ftabel (2.489525 > 1.66757), maka H1 ditolak dan H2 diterima berarti dalam jangka pendek variabel perubahan presentase volume pembiayaan murabahah yang terdapat dalam model berpengaruh secara signifikan terhadap variabel ROA.

\section{KESIMPULAN}

Berdasarkan hasil penelitian yang telah dilakukan maka diperoleh kesimpulan Pembiayaan bagi hasil memiliki pengaruh signifikan terhadap kinerja bank umum syariah (ROA). Pada pembiayaan bagi hasil bank umum syariah sebagai pemilik modal tinggi mendapatkan keuntungan yang maksima agar bagi hasilnya juga memuaskan. Hasil penelitian yang kedua pembiayaan murabahah berpengaruh signifikan terhadap ROA. Variabel ini menjelaskan keberagaman usaha pada bank umum syariah serta pembiayaan murabahah juga merupakan sumber utama pendapatan bank umum syariah.

Nilai $\mathrm{R}^{2}$ sebesar 0.362370 menunjukkan bahwa $36 \%$ perubahan pada variabel ROA mampu dijelaskan oleh variabel-variabel bebasnya dalam persamaan jangka panjang dan sisanya sebesar $64 \%$ dijelaskan oleh factor lain diluar model. Hasil uji F-statistik menunjukkan

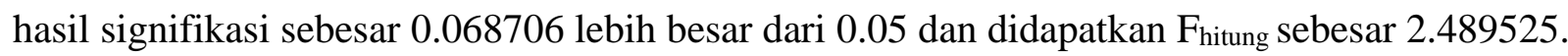
jadi Fhitung lebih besar dari Ftabel (2.489525 > 1.66757), berarti dalam jangka pendek variabel perubahan presentase volume pembiayaan murabahah yang terdapat dalam model berpengaruh secara signifikan terhadap variabel ROA.

\section{E. DAFTAR PUSTAKA}

Afrida, Yenti. "Analisis Pembiayaan Murabahah Di Perbankan Syariah." Jebi (Jurnal Ekonomi Dan Bisnis Islam) 1, no. 2 (2016) http://journal.febi.uinib.ac.id/index.php/jebi/article/view/32.

Agza, Yunita, and Darwanto Darwanto. "Pengaruh Pembiayaan Murabahah, Musyarakah, Dan Biaya Transaksi Terhadap Profitabilitas Bank Pembiayaan Rakyat Syariah.” Iqtishadia: Jurnal Kajian Ekonomi dan Bisnis Islam STAIN Kudus 10, no. 1 (2017).

Angraini, Dila. "Pengaruh Dana Pihak Ketiga, Non Performing Financing, Tingkat Bagi Hasil Dan Modal Sendiri Terhadap Profitabilitas Dengan Pembiayaan Bagi Hasil Sebagai Variabel Intervening Pada Perbankan Syariah." Jurnal Akuntansi Berkelanjutan Indonesia 1, no. 1 (2018).

Azhar, Ian, and Arim Nasim. "Pengaruh Pembiayaan Jual Beli, Pembiayaan Bagi Hasil, Dan Non Performing Finance Terhadap Profitabilitas (Studi Kasus Pada Bank Umum Syariah Di Indonesia Periode 2012 - 2014)." Jurnal ASET (Akuntansi Riset) 8, no. 1 (2016).

Aziza, Ratu Vien Sylvia, and A D E Sofyan Mulazid. “Analisis Pengaruh Dana Pihak Ketiga, 
Non Performing Financing, Capital Adequacy Ratio, Modal Sendiri Dan Marjin Keuntungan Terhadap Pembiayaan Murabahah.” Jurnal Ekonomi dan Bisnis Islam (JEBI) 2 (2015).

Azmi, Fika. "Analisis Pengaruh Volume Pembiayaan Terhadap Profitabilitas Dengan BOPO Sebagai Variabel Moderasi Pada Bank Umum Syariah Di Indonesia.” Ebbank 7, no. 2 (2016). http://ebbank.stiebbank.ac.id/index.php/EBBANK/article/view/97.

Destiana, Rina. “Analisis Dana Pihak Ketiga Dan Risiko Terhadap Pembiayaan Mudharabah Dan Musyarakah Pada Bank Syariah Di Indonesia." LOGIKA Jurnal Ilmiah Lemlit Unswagati Cirebon 17, no. 2 (2016).

Fadhila, Novi. "Analisis Pembiayaan Mudharabah Dan Murabahah Terhadap Laba Bank Syariah Mandiri." Riset Akuntansi Dan Bisnis 15, no. 1 (2015).

Fathimah, Vidya. "Pengaruh Perkembangan Jumlah Tabungan, Deposito Dan Bagi Hasil Terhadap Jumlah Pembiayaan Yang Diberikan Oleh Perbankan Syariah Di Sumatera Utara." Jurnal Ilman 5, no. 1 (2017).

Fauziah, Heftika Nur, Aini Nur Fakhriyah, and Abdurrohman Abdurrohman. "Analisis Risiko Operasional Bank Syariah Pada Masa Pandemi Covid-19.” Al-Intaj Jurnal Ekonomi dan Perbankan Syariah 6, no. 2 (2020).

Kholmi, Masiyah. "Ekonomi Dan Bisnis." Akuntabilitas dalam Perspektif Teori Agensi 02, no. 02 (2010).

M, Muh Sabir, Muhammad Ali, and Abd Hamid Habbe. "Pengaruh Rasio Kesehatan Bank Terhadap Kinerja Keuangan Bank Umum Syariah Dan Bank Konvensional Di Indonesia." Jurnal Analisis 1, no. 1 (2012).

Notoadmojo, Iqbal, and Anita Rahmawaty. "Analisis Faktor-Faktor Yang Memengaruhi Financial Sustainability Ratio Pada Bank Umum Syariah Di Indonesia Periode 2010 - 2014.” Equilibrium: Jurnal Ekonomi Syariah 4, no. 1 (2017).

Oktarina, Amimah, and Asnaini Asnaini. "Potensi Kontribusi Institusi Pendidikan Islam Terhadap Perkembangan Bank Syari'ah Di Indonesia.” Al-Intaj : Jurnal Ekonomi dan Perbankan Syariah 6, no. 1 (2020).

Otoritas Jasa Keuangan. “Statistik Perbankan Syariah Agustus 2020” (2020).

Penyelamatan, Strategi, Pembiayaan Bermasalah, Pada Pembiayaan, Murabahah Di Bank, Syariah Mandiri, and Cabang Purwokerto. "Januari-Juni 2016 Referring to the NPF Data of Syariah Mandiri Bank.” Junal Ekonomi Islam el-JIZYA 4, no. 1 (2016): 2015.

Prabowo, Bagya Agung. "Konsep Akad Murabahah Pada Perbankan Syariah (Analisa Kritis Terhadap Aplikasi Konsep Akad Murabahah Di Indonesia Dan Malaysia).” Jurnal Hukum Ius Quia Iustum 16, no. 1 (2009).

Sodiq, Amirus, and Ela Chalifah. "Pengaruh Pendapatan Mudharabah Dan Musyarakah Terhadap Profitabilitas (ROA) Bank Syariah Mandiri Periode 2006-2014." EQUILIBRIUM:Jurnal Ekonomi Syariah 3, no. 1 (2015).

Sofhian, and Sri Nur Ain Suleman. "Manajemen Penyelesaian Pembiayaan Bermasalah Pada Lembaga Perbankan.” Jurnal Studi Ekonomi dan Bisnis Islam I (2017).

Sudarwati, Lilis. "Pengaruh Pembiayaan Bagi Hasil Dan Pembiayaan Jual Beli Terhadap Profitabilitas (Roa) Dengan Non Performing Financing (Npf) Sebagai Variabel Intervening." Skripsi, IAIN SALATIGA (2018).

Wahyuni, Mirasanti. "Pengaruh Volume Pembiayaan Bagi Hasil Dan Pembiayaan Murabahah Terhadap Kinerja Keuangan Bank Umum Syariah Dengan NPF Sebagai Variabel Moderasi." Jurnal EBBANK 7, no. 1 (2016).

Widiarsih, Dwi, and Reza Romanda. "Analisis Faktor-Faktor Yang Mempengaruhi Inflasi Di 
Indonesia Tahun 2015-2019 Dengan Pendekatan Error Corection Model (ECM)." Jurnal Akuntansi dan Ekonomika 10, no. 1 (2020).

Wilarjo, Setia Budhi. "Pengertian, Peranan, Dan Perkembangan Bank Syariah Di Indonesia." Igarss 2014 2, no. 1 (2014). 